\title{
Giant synovial cell sarcoma of the thorax in a 46-year-old man: a
}

\section{case report}

\author{
Saulat Hasnain Fatimi ${ }^{1}$ and Taimur Saleem ${ }^{* 2}$
}

\author{
Address: ${ }^{1}$ Department of Surgery, Division of Cardiothoracic Surgery, Aga Khan University, (Stadium Road), Karachi, (74800), Pakistan and \\ ${ }^{2}$ Medical College, Aga Khan University, (Stadium Road), Karachi, (74800), Pakistan \\ Email: Saulat Hasnain Fatimi - saulat.fatimi@aku.edu; Taimur Saleem* - taimur@gmail.com \\ * Corresponding author
}

Published: 15 December 2009

Cases Journal 2009, 2:9324 doi:10.1186/1757-1626-2-9324

This article is available from: http://www.casesjournal.com/content/2/I/9324

(c) 2009 Fatimi and Saleem; licensee BioMed Central Ltd.

This is an Open Access article distributed under the terms of the Creative Commons Attribution License (http://creativecommons.org/licenses/by/2.0), which permits unrestricted use, distribution, and reproduction in any medium, provided the original work is properly cited.

\begin{abstract}
Background: Although synovial cell sarcoma is a common tumor of the extremities, its occurrence in the thorax has been less frequently documented.

Case presentation: A 46-year-old Pakistani man presented with a 2 month history of progressively increasing cough and left lower chest pain. Initial evaluation was done using a chest $\mathrm{x}$-ray; the patient was found to have a large mass involving the lower portion of the left chest. A computed tomography scan was performed next which showed a large mass involving the left chest wall with invasion into the pericardium and left hemidiaphragm. En bloc surgical resection of the tumor was undertaken. Final pathology showed synovial cell sarcoma of the thorax. At one-year follow-up, the patient has shown no recurrence of the disease.

Conclusion: We have described a rare case of a large synovial cell sarcoma of the thorax. Surgical resection appears an appropriate modus operandi for managing giant synovial cell sarcomas of the thorax. However, there is a need to clearly define post-operative strategies for cases with extensive involvement of surrounding structures.
\end{abstract}

\section{Background}

Synovial cell sarcoma (SCS) is a common tumor of the extremities. However, SCS of the thorax is an overall rare clinical entity. We report here a case of SCS in a 46-yearold man with extensive involvement of the chest wall, lung and diaphragm.

\section{Case presentation}

A 46-year-old Pakistani man presented to our hospital with a 2 months history of progressively increasing cough and left lower chest pain. Initial evaluation was done using a chest $\mathrm{x}$-ray and he was found to have a large mass involving the lower portion of the left chest. Computed tomography (CT) scan was obtained next to better delin- eate the disease process (Figure 1). It showed a $16 \times 15 \mathrm{~cm}$ mass involving the left chest wall and left lower lobe of the lung with invasion into the pericardium and left hemidiaphragm. There was no pericardial or pleural effusion. CT scan of the abdomen-pelvis was normal.

Trucut biopsy of this mass showed features of SCS. In the absence of effective chemotherapy and obvious metastasis, the patient was planned for a complete resection of this tumor. The tumor was exposed via a left posterolateral thoracotomy approach. Intra-operatively, a large tumor with extensive involvement of the left lower chest wall from the 4 th to $10^{\text {th }}$ ribs was seen. It was also involving the left lower lung lobe, left hemidiaphragm and peri- 


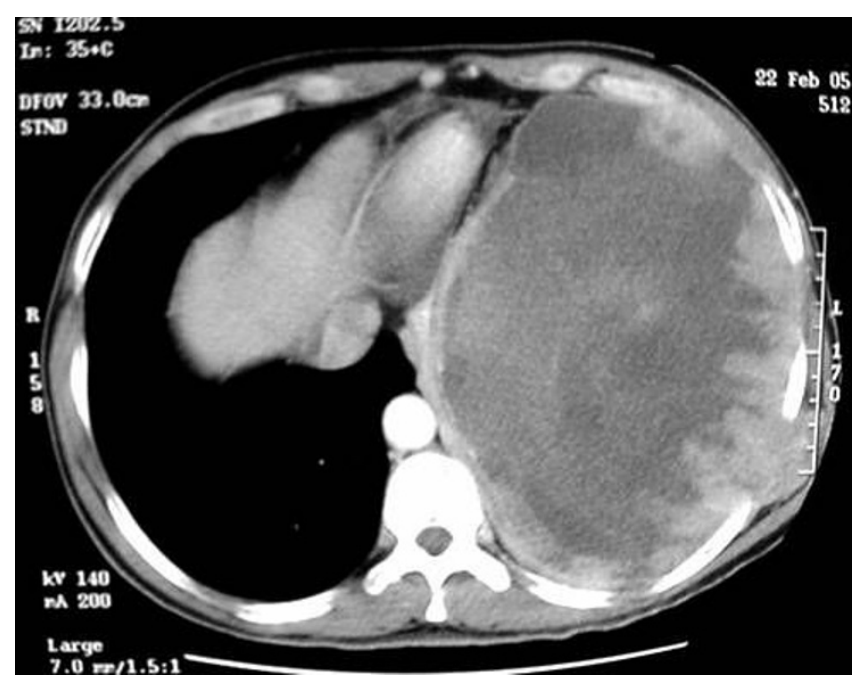

Figure I

Computed tomography scan of the chest showing a large synovial cell sarcoma with extensive involvement of surrounding structures.

cardium (Figure 2). The mass was removed en bloc with all involved ribs, left lower lung lobe, left hemidiaphragm and pericardium. Final pathology confirmed it to be SCS sarcoma with negative histological margins. The post operative course of the patient was unremarkable. He was discharged on the 9th postoperative day. At follow-up after one year, the patient has shown no recurrence of the disease.

\section{Discussion}

SCS is a malignant tumor that has been termed such because of histological resemblance to developing syn-

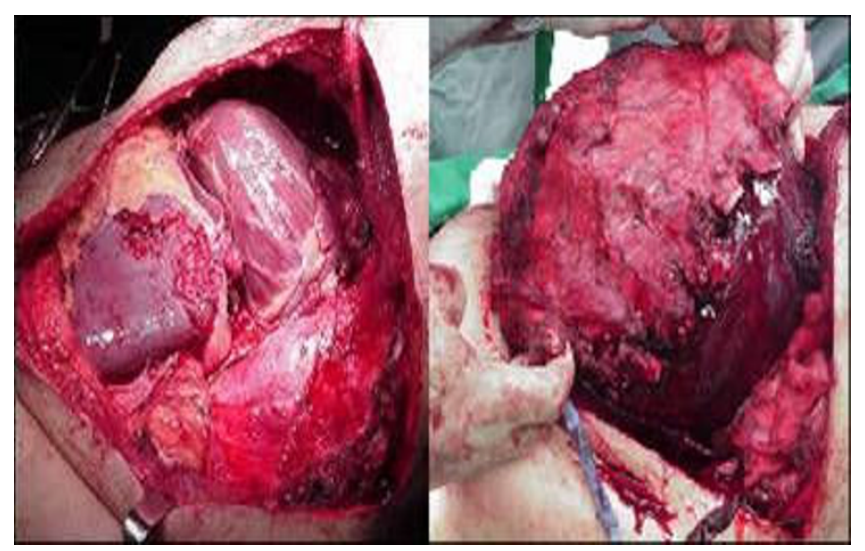

Figure 2

Large synovial cell sarcoma with extensive involvement of the chest wall, pericardium, left hemidiaphragm and left lower lung lobe. ovium [1]. It is thought to arise from primitive pluripotent mesenchymal cells rather than the synovium [2]. SCS is the third most common sarcoma of the extremities after liposarcoma and malignant fibrous histiocytoma [3] and has been found to account for 5 - 14\% of soft tissue sarcomas in different studies $[1,4,5]$. Apart from the extremities, SCS may also occur in the pericardium, pleura, lung, sternum, esophagus, retroperitoneum, mediastinum, mesentery, head and neck, abdominal and thoracic wall, prostate and kidney; albeit with lesser frequency.

SCS of the thorax represents a diagnostic challenge because of the diverse array of competing diagnosis and rarity of incidence [6]. The symptoms of a patient with SCS of the thorax depend on the structures undergoing compression or invasion from the tumor. Patients may present with chest pain, coughing, hemoptysis, dyspnea, reduced breath sounds and weight loss. Primary thoracic SCS sarcomas typically occur as chest wall masses that exhibit a propensity for invasion into surrounding structures. Immunohistochemically, synovial sarcomas show immunoreactivity for cytokeratins, EMA, S-100 protein, are positive for Bcl-2, O-13, Actin and negative for CD34 and Desmin [7]. Young age, Her-2 expression, complete resection with clear surgical margins and response to first line chemotherapy were found as good prognostic indicators in advanced disease in different studies $[1,8,9]$. Adverse prognostic factors for SCS include lesions larger than $5 \mathrm{~cm}$, male gender, extensive tumor necrosis, neurovascular invasion, aneuploidy and poor histological differentiation $[4,10,11]$. Definitive diagnosis of SCS can be made with biopsy and use of immunohistochemistry, electron microscopy and cytogenetic analysis [6,12]. CT scan and magnetic resonance imaging (MRI) are imaging modalities employed for the evaluation of respectability and staging of the neoplasm.

Treatment of choice for SCS sarcomas of the thorax is excision, radiation therapy and adjuvant chemotherapy following resection. In our case, successful surgical resection was performed for a large synovial sarcoma of the left chest wall with involvement of left lung, pericardium and left hemidiaphragm. The diaphragm and left chest wall had to be reconstructed with prolene mesh and muscle flap after complete resection of tumor. Our patient is not receiving any radiation therapy because of proximity of the bare heart to the chest wall. Also, the need for adjuvant therapy was obviated because of achievement of histologically negative margins. As SCS is known to recur, the patient needs to be followed up carefully.

\section{Conclusion}

We have documented a rare case of a giant SCS of the thorax with extensive involvement of surrounding structures. This is a rare clinical entity and there is a need to clearly 
define post-operative strategies for a case with extensive involvement like ours.

\section{Abbreviations}

CT: computed tomography; MRI: magnetic resonance imaging; SCS: synovial cell sarcoma.

\section{Consent}

Written, informed consent was obtained from the patient for the publication of this case report and accompanying images. A copy of the consent form is available for review by the Editor-in-Chief of the journal.

\section{Competing interests}

The authors declare that they have no competing interests.

\section{Authors' contributions}

TS was involved in data collection, interpretation and drafting the manuscript. SHF was involved in study design and conception, data interpretation, drafting the manuscript and providing overall supervision in the project. All authors read and approved the final manuscript.

\section{References}

I. Spurrell EL, Fisher C, Thomas JM, Judson IR: Prognostic factors in advanced synovial sarcoma: an analysis of 104 patients treated at the Royal Marsden Hospital. Ann Oncol 2005, 16:437-444.

2. Cappello F, Bellafiore M, Bucchieri F, Balsano G, Palma A, Zummo G: Poorly differentiated synovial sarcoma: a case report. Pathol Oncol Res 200I, 7:63-66.

3. Russell WO, Cohen J, Enzinger F, Hajdu SI, Heise H, Martin RG, Meissner W, Miller WT, Schmitz RL, Suit HD: A clinical and pathological staging system for soft tissue sarcomas. Cancer 1977, 40: $1562-1570$.

4. Marzano L, Failoni S, Gallazzi M, Garbagna P: The role of diagnostic imaging in synovial sarcoma. Our experience. Radiol Med 2004, 107:533-540.

5. Bégueret $H$, Galateau-Salle F, Guillou L, Chetaille B, Brambilla E, Vignaud JM, Terrier P, Groussard O, Coindre JM: Primary intrathoracic synovial sarcoma: a clinicopathologic study of $40 \mathrm{t}$ $(X ; 18)$-positive cases from the French Sarcoma Group and the Mesopath Group. Am / Surg Pathol 2005, 29:339-346.

6. $\mathrm{Ng} \mathrm{SB}$, Ahmed Q, Tien SL, Sivaswaren C, Lau LC: Primary pleural synovial sarcoma: a case report and review of the literature. Arch Pathol Lab Med 2003, I 27:85-90.

7. Zamarrón C, Abdulkader I, Alvarez UC, Barón FJ, Prim JM, Ledo RL, Forteza J: Primary Synovial Sarcoma of the Lung. Intern Med 2006, 45:679-683.

8. Sápi Z, Pápai Z, Hruska A, Antal I, Bodó M, Orosz Z: Her-2 oncogene amplification, chromosome 17 and DNA ploidy status in synovial sarcoma. Pathol Oncol Res 2005, I I: | 33- I 38.

9. Régnard JF, Icard P, Guibert L, de Montpreville VT, Magdeleinat P, Levasseur $P$ : Prognostic factors and results after surgical treatment of primary sarcomas of the lung. Ann Thorac Surg 1999, 8:227-23I.

10. el-Naggar AK, Ayala AG, Abdul-Karim FW, McLemore D, Ballance WW, Garnsey L, Ro JY, Batsakis JG: Synovial sarcoma. A DNA flow cytometric study. Cancer 1990, 65:2295-2300.

II. Trassard M, Le Doussal V, Hacène K, Terrier P, Ranchère D, Guillou L, Fiche M, Collin F, Vilain MO, Bertrand G, Jacquemier J, SastreGarau X, Bui NB, Bonichon F, Coindre JM: Prognostic factors in localized primary synovial sarcoma: a multicenter study of I 28 adult patients. J Clin Oncol 200I, 19:525-534.

12. Terasaki H, Niki T, Hasegawa T, Yamada T, Suzuki K, Kusumoto M, Fujimoto K, Hayabuchi N, Matsuno Y, Shimoda T: Primary synovial sarcoma of the lung: a case report confirmed by molecular detection of SYT-SSX fusion gene transcripts. Jpn J Clin Oncol 200I, 3I:2I 2-2I6.
Publish with Biomed Central and every scientist can read your work free of charge

"BioMed Central will be the most significant development for disseminating the results of biomedical research in our lifetime. "

Sir Paul Nurse, Cancer Research UK

Your research papers will be:

- available free of charge to the entire biomedical community

- peer reviewed and published immediately upon acceptance

- cited in PubMed and archived on PubMed Central

- yours - you keep the copyright
BioMedcentral 